\title{
Revisiting the Vāstupuruṣamaṇḍala in Hindu Temples, and Its Meanings
}

\author{
Young Jae Kim
}

Ph.D. in Architectural History and Theory (University of Pennsylvania, USA)

http://dx.doi.org/10.5659/AIKAR.2014.16.2.45

\begin{abstract}
The objective of this article, positively recognizing existing researches, is to revisit some aspects regarding the Vāstupurușamanḍala with a square grid work which is a fundamental planning guideline to control the construction of a Hindu temple and a mathematical doctrine to lead ritual programs. Hence, this paper suggests some reservations as to certain details such as temple constructions. In order to lay hold on its meaning, this paper touches upon the specific matters about the Vāstupuruṣamandala in the building construction of Hindu temples, which set out to shed light on four concerns; first, it explores the formation process of the Vāstupurușamaṇạala in concert with the evolution of Hindu temples over time; second, it considers differences and similarities in comparison with other texts intimately articulated with the construction of temples, and then understands the relationship between their local languages and applications to the Vāstupurușamandiala; third, it examines the symbolic and sanctified process of the temple's construction on the Vāstupurușamandala grids with two- or three- dimensional computer graphics (by means of the Auto Cad and Rhino tools), invisibly situating the divinities within it and illuminating the roles of ornamentation in the structural terms of temples; fourth, it presents that there are another rules on the building construction based upon architect-priest's craftsmanship skilled as a stonemason or a carpenter in the manual processes of the temples' construction for proper measurements and truncations of stone and wood closely linked together structural stability of completed temples. In conclusion, proceeding from what has been said above, this thesis shows that the Vāstupuruṣamaṇạala grid includes both practical and spiritual meanings to construct a Hindu temple.
\end{abstract}

Keywords: Vāstupurușamaṇḍala, Grid Diagram, Ritual Instrument, Structural Stability, Hindu Temple, Nāgara, Drāvida, Vesara

\section{INTRODUCTION}

A temple is a ritual instrument, and its ultimate function is to bind together individuals and communities into a complicated and inconsistent social structure through the times. As one of rules which construct a temple, the Vāstupurușamaṇdala controls a temple's form and its meaning as a representative design-governing tool. Such unification for ritual communities was invisible until the fifth century CE. Since then, in the temple architecture, the application of the Vāstupurușamaṇdala through which a ritual grid transmitted sanctity to worshippers. Formalization by a diagram was a revolutionary upheaval in designing a temple. Hindu temples likewise embody their evolution through the empathy and identification of signs, which are the learned responses of specific cultural experiences stemmed from the Vedic tradition. Temples are depicted as deities' house by means of an iconographic program

Corresponding Author: Young Jae Kim, Ph.D. in Architectural

History and Theory

376-10, Daebang-dong, Dongjak-gu, 156-809, Seoul, Korea

Tel: +82 28153975 e-mail: kyjwow@gmail.com

This is an Open Access article distributed under the terms of the Creative Commons Attribution Non-Commercial License (http://creativecommons. org/licenses/by-nc/3.0/) which permits unrestricted non-commercial use, distribution, and reproduction in any medium, provided the original work is properly cited. and repeated copies of images, producing a dramatic sense of symbolism. The form and meaning as a ritual instrument become gradually fixed as a universal idea, which contributes to ceremonial procedure, spatial layouts, iconographic concepts, and even structural stability.

The objective of this article, positively recognizing existing researches as a consequence of the selection in the pursuit of sources, is to revisit some aspects with regard to the Vāstupurușamaṇạala working with square grid, which is both a fundamental planning guideline to control the construction of a Hindu temple and a mathematical doctrine to lead ritual programs. Hence, this paper suggests some reservations as to certain details such as temple constructions led by craftsmen. In order to lay hold on its meaning, as a result, this study touches upon the specific matters about the Vāstupurușamandala in the building construction of Hindu temples, which set out to shed light on four concerns; first, it explores the formation process of the Vàstupurușamanḍala in concert with the evolution of Hindu temples over time; second, it considers differences and similarities in comparison with other texts intimately articulated with the construction of temples, and then understands the relationship between their local languages and applications to the Vàstupuruṣamaṇḍala; third, it examines the symbolic and sanctified process of the temples construction on the Vāstupuruṣamandịala grids with two- or three- dimensional computer graphics (by means of the Auto Cad and Rhino tools), invisibly situating the divinities within it and illuminating the roles 
of ornamentation in the structural terms of temples; fourth, it presents that there are another rules on the building construction based upon architect-priest's craftsmanship skilled as a stonemason or a carpenter in the manual processes of the temples' construction for proper measurements and truncations of stone and wood closely linked together structural stability of completed temples. In conclusion, proceeding from what has been said above, this thesis shows that the Vāstupurușamaṇala grid includes both practical and spiritual meanings to construct a Hindu temple, answering people's needs and expectations.

\section{HINDU TEMPLE AND VĀSTUPURUSAMANDALA}

\subsection{Temple's Evolution and Emergence of the Vāstupurusamandala}

Indian Hindu temples are generally enclosed by the use of towering walls or cloistered of subordinate structures which consist of carved miniatures with great thickness, multi-storey with pilastered walls, and one-fourth of the inner width of a sanctuary. These walls enshrine a symbol or an image for deities to whom a temple would be consecrated. The temples maintain their symbolic metaphor as a body and a mountain, and their sancta as a womb (garbhagrha) or a cave (Kim, 2011b, 32-35). ${ }^{1}$ Such sacred structures that enclose objects for worship were constructed for centuries before the birth of temple structures. In other words, something like tree-shrines marked by a vertical axis (such as tree, snake, pillar, and standing Yaksa) within a square railing (Staal, 1984; Meister, 2003, 251-290) ${ }^{2}$ was worshipped in various places (Meister, 1991, 269-280). Originally, Hindu temples are connected to dolmens (stone circles), as well as altars and huts in the Vedic eras. Such information is preserved in the manuals of astrology and architecture. The early rock-cut caves in North and South India were constructed as a house for their gods, beginning in the south India (Udayagiri, Madhya Pradesh, ca. $400 \mathrm{CE}$ ). They spread to Southern areas such as Badami, Aihole, and Mahabalipuram, dated to the third quarter of the sixth century. Even earlier, temples built in materials other than stone apparently used a typical form derived from urban and domestic architecture in order to shape a towering structure (Meister, 1989, 254-280).

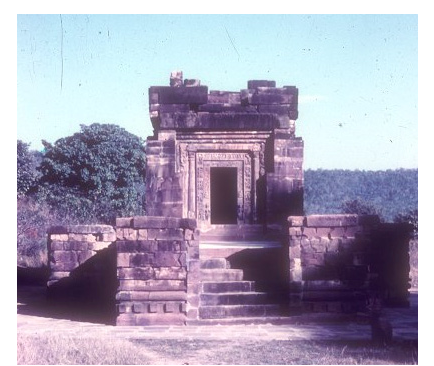

Figure 1. Pārvatī temple,

Nachna, c465 (source: author)

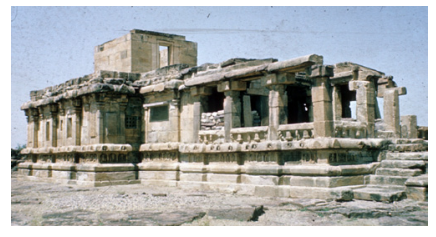

Figure 3. Meguti temple, Aihole, c634(source: author)

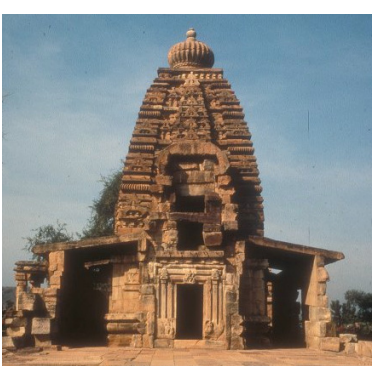

Figure 2. Galaganātha temple, Pattadakal, $7^{\text {th }} c$ (source: author)

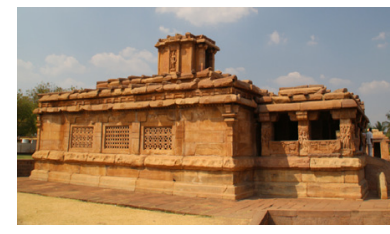

Figure 4. Lad Khan temple, Aihole, $7-8^{\text {th }} c$ (source: author)
Then, a simple stone temple, like Nachna (Madhya Pradesh, 465 $\mathrm{CE}),{ }^{3}$ started to be built as a regular square - commonly applied plan from the fifth through the tenth century is square in plan (Mayamata, 1985, 3, 2.10-15a). ${ }^{4}$ The Nachna temple, enshrining Pārvatī, shows an attempt to build a new temple in the Gupta period. It has an uppermost structure with a three-layered flat roof, preparing for the beginning of a towering structure. Galaganātha temple (the seventh century) at Pattadakal presents the emergence of a towering structure as a mountain or a palace (Skt. prasāda) for Siva who resides at Mt. Kailāsa (Fig. 1, 2), whereas Meguti temple (that an inscription mentions its foundation in $634 \mathrm{CE}$ ) and Lad Khan temple (following stylish tendencies in the late seventh or early eighth century) at Aihole are upgraded flat-roofed temples with an upper shrine because they include images attached outside the roof shrines (Tartakov, 1980, 80-84). ${ }^{5}$ (Fig. 3, 4) Later in the centuries, its walls or built forms that surround an inner sanctum and a towering structure directly built above it match successfully with grids as a strong sign of Vāstupurușamaṇdala after the fifth century to make manifest the presence of the divine in addition to gaining a merit by creating clear measurements and proportions.

Even earlier temples in the north India consisted only of the sanctum, and then the brick altar's sacred diagram was used for the enshrined divinity developed relatively later in India, at least in the fifth century, as recorded in Varahamihira's early sixthcentury text that mentions the Vāstupurușamaṇdala's rule. The appearance of stone temples, to put it another way, is conformable with that of Vāstupurușamaṇdala. It surely resonates that stone is a highly useful material in covering the rule by construction methods in addition to its durability, rather than brick because it coincides with ultimate purposes of temples as a palace and house of divinity. Only in the late seventh or the early eighth century, a crowning àmalaka (borrowing the form of southern Dravidian temples) above vedika (threshold railing) including a neck (griva) and a finial (stūpi) was established on the curvilinear form of northern Nāgara temples (Meister, 1986, 33-50). Likewise, an independent space was considered. An assembly hall (mukhashala, mahāmaṇdapa) for a spacious space of lighting was erected for worshippers facing toward a sanctum via antarāla (intermediate space) (Meister, 1989, 254-280; Meister, 1978, 409-418). The entrance was framed by an elaborate doorway with a simple porch with two pillars. As a significant design tool and ritual plan, simultaneously, the construction of temples complies with proportional and regular rules according to such major sources as the Brihat Samhitâ and the Mayamatam. The temples in the seventh or early eighth centuries conform to such rules, and in each region they interpret such rules in response to each method (Meister, 1979, 205). Their circumambulatory ritual passageways, an integral part of the pilgrimage activity, are made in between a sanctum and enclosed walls behind corridors. They are applied consistent with a special formula and a modular proportioning for a grid ritual. Consequently, these big changes in the eighth century are ascribed to two reasons; the first is the formalization of Hindu ceremonies, and the second results from the completion of the Vāstupurușamaṇdalàs rule and the proliferation of temples that apply this rule. This significant growth is fairly coupled with the publication of the related manuscript. Likewise, as for these changes of construction methods and the extension of ritual spaces, the generative influence upon certain powers of the Gupta Empire 
(320-550 CE) cannot be ignored during about the late fourth to the sixth centuries because the Gupta kings support Brahmans who regard the kings as a man of the divine. ${ }^{6}$ Unlike the thick-walled temples of the Gupta age (Kramrisch, 1946, 228), meanwhile, there are another stone temples with thin-walled shrines called 'mand dapikä built as funereal monuments in Central India from the sixth to tenth centuries CE (Meister, 1978). ${ }^{7}$ At all events, from the sixth century onward, obviously throughout India the stone temples flourish, and distinguishing regional styles emerge.

\subsection{On the Vāstupurusamandala's Materials in Comparison with Others}

Essential textual evidences for governing a mandiala do not come from technical manuals, but the Brahmanical cults concerned with the making of altars and the offering of sacrifices (Renou, 1972). In such sense, the Srautasūtra is an important text oriented to delineations about the Vedic altar of the fourth to third century BCE. The text includes any ways as regards measuring the altars and performing the sacrifice as a geometric structure. The oldest references to architectural planning are actually from the Arthaśāstra, written in the late fourth century, which is more coupled with the issues of social organization, statecraft, and policy matters (Kauțalya, 2004, 254-257; Keith, 1928). The later Silpa Praksa illustrates the regional method of Orissan temples (possibly the 10th century CE) (Boner, 1966). ${ }^{8}$ Several chapters in the Agamas and the Puranas, encyclopedic, and mathematic or ritualistic texts suggest the planning of architecture (Bafna, 2000, 26-28).

As regards mandala tools, on the one hand, what should be noted is Varāhamihirảs Bṛihat Saṃhitâ, a treatise on astrology and augury compiled early in the sixth century CE; the text, adding other earlier texts, first suggests embodied plans to design and construct cities and buildings, subsuming rules referred to the Vāstupurușamaṇdala and describing the primitive practice of Vedic sacrifice. In Chapter 53, 'On the Building of Temples', it records a diagram as a ritual tool, illustrating "places suitable for the erection of houses for the Brahmins and others are suitable for the erection of temples. In the case of temples, the site shall always be divided into 64 squares and the entrance in the middle of the wall shall be due east and west and due north and south." Also, it specifically mentions the size of garbhagrha (inner sanctum), "it shall be half as broad as the breadth of the temple, and its height shall be twice its breadth." Besides, varied house structures, their class linkage, orientation, multi-storey buildings, and balconies are stipulated throughout it.

On the other hand, comparable statements with Brihat Saṃhitâ are found in the Mayamatam and the Mānasāra that cover the generic interpretation of the south India as to the Vâstupurușamandiala. They provide priest-architect's craftsmanship as a stonemason or a carpenter for grid applications articulated with the Vāstupuruṣamaṇdala to place buildings into an overall plan, and for an operational instruction of town layouts and a significance of points (marmas). The Vastusutra Upanishad gives another practice on something like the Vāstupurușamaṇụala, and indeed it mentions a process that grids are made meeting circle and square and deities are located within the unit, and then a process of drawing of a $4 \times 4$ orthogonal grid as an altar, namely a compositional diagram, khila-pañjara (Boner, 1996, 47-51).
These three manuscripts also discuss vulnerable crossings (marma, displacement of pillars and walls) which should protect Brahman from injury (Varāhamihira, 1947, 438-440), in addition to a range of magical association and wood architectural practice.

Further, another closest source to any kind of a geometric entity is the Sulbasūtra recorded in the third-fourth centuries BCE. The text provides a design method with a geometric construction, applying cords to draw circles which have to locate square and cardinal orientations, essential for a plot of land to build a sacrificial altar. It also might be appropriated to create a new form in the base of Vāstupurușamandala. To put otherwise, it illustrates methods for taking a rope for a required square (Meister, 1981, 83-84). As a remarkable instance about the application of these two rules, there is the twelve-sided stone temple at Indor (the mid-eighth century). ${ }^{9}$ The temple provides an evidence for the interaction between the ritual geometry of the Vāstumaṇdala (Meister, 1982, 302-320) although most Vedic literature does not adequately distinguish between squares and other quadrilaterals. This thus can be an obvious proof that the Vāstupurusamaṇ ḍala was taken into consideration to embody a geometrical diagram in the temple at Indor. Although there are many differences and similarities between them, a remarkable sharing for these texts shows that worshippers wish to enter the worlds which would be in auspicious environments for happiness, reached by 'meritorious deeds' by activities for building a temple to the gods (Varāhamihira, 1884, 7477). It adds a further dimension about the construction of a temple.

\subsection{Applying the Vāstupurusamandala to Local Languages of Temples}

Hindu temples are largely classified into two types, 'Nāgara' (the typical North Indian) and 'Drāviḍa' (the typical South Indian). On Nāgara and Drāviḍa, a trial to divide them has a long history. The South Indian texts suggest that major points which decide Nāgara temple are whether its plan is square or not, and whether its superstructure is square śikhara (cupola) and square stūpi (finial) or not (Dhaky, 1977, 9-11). ${ }^{10}$ In North India, Nāgara temples are preserved in stone only from the early fifth century $\mathrm{CE}$, whereas stone temples in South India do not appear until the seventh century CE. The Nàgara temple, curvilinear in outline, is constructed with laminated planes by ribbed āmalaka stones on the corners and divided vertical creepers (latās) by offsets (bhadra), extending into the superstructure, while the Drāvida temple is originated from a model of 'rathas' literally 'chariots' which provides a variety of structures: a hut, two-three storeyed terraced pyramidal structures with square or octagonal crowning domes, an oblong, keel-roofed shrine, and an apsidal hall, which are sustained as a morphology of forms typical of Drāvida throughout its long history. (Fig. 5, 6) On the contrary, a mixed style, called 'Vesara', appears at the beginning of the sixth century. In the progress of the Vesara type, the sixth to the eleventh century CE is a very important epoch in the history of South Indian architecture and allied arts (Srinivasan, 1975; Hardy, 2001, 180-199). The remarkable changes are monuments erected in Karnataka area under the Badami Chalukya dynasty (often called early Chalukya) in the southwest Deccan around Badami. The local temples are not immediately recognizable as Drāvidia until the early Chalukya period, rather closer to the Nāgara form owing to Gupta temples impact. In the Chalukya period they become more distinct from the conservative 
Tamil Drāviḍa, rather with Nāgara seeming aspects and newlycreated Karnataka Drāviḍa language.

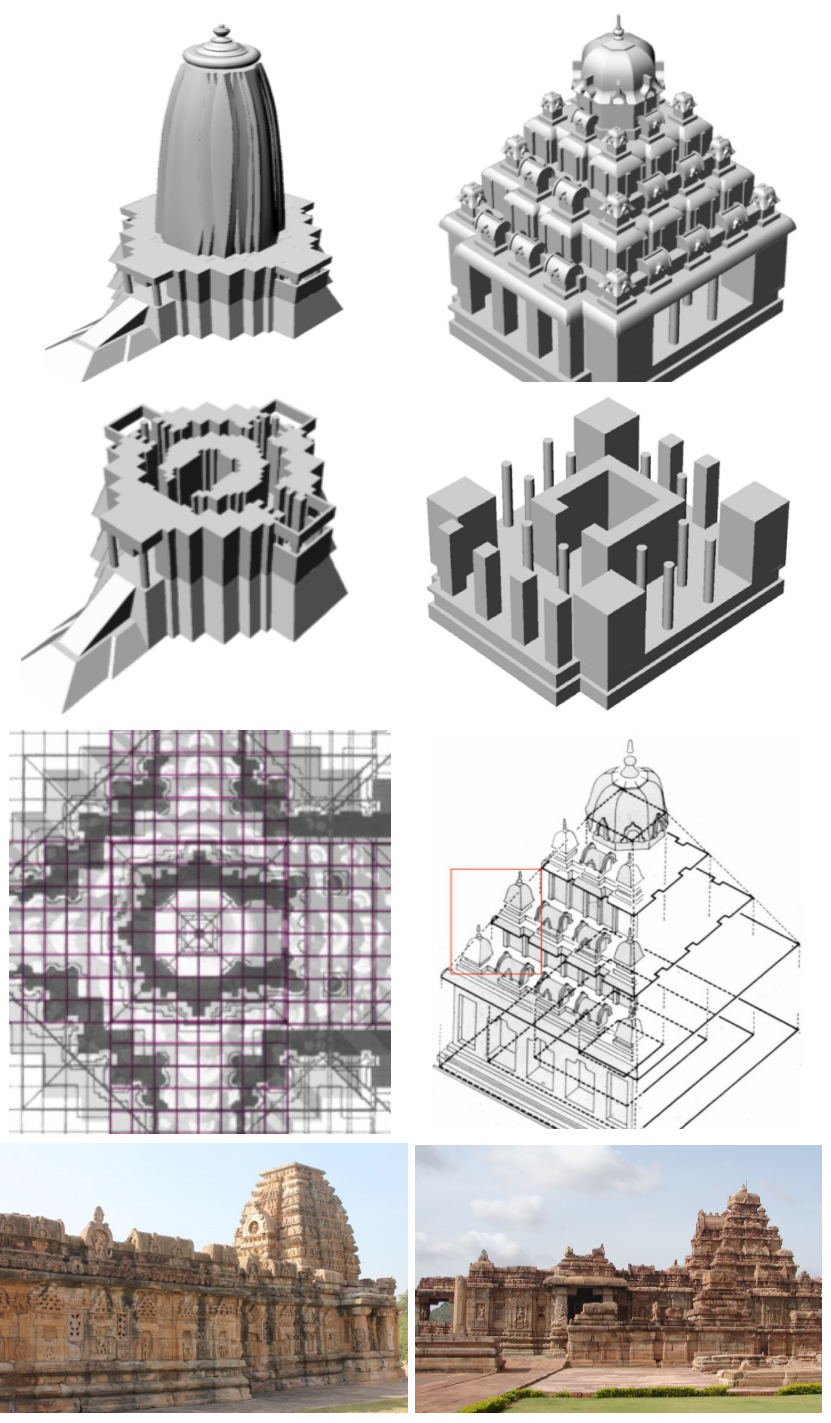

Figure 5. Upper: Nāgara(L) and Drāviḍa(R). Lower: Nāgara(L)/ Drāviḍa(R)'s sectional plan cut below a superstructure (author's drawing)

Figure 6. Nāgara(L) and Drāviḍa(R) temples overlaid on the Vāstupuruṣamaṇ ḍala grids (author's drawing and Meister)

Figure 7. Two Vesara styles, Nāgara(upper body)-Drāviḍa(lower body) (L)(source: author) Drāviḍa(upper body)-Nāgara(lower body)(R)

Both styles therefore coexist at that time. The fused style is named 'Vesara' that means a mule. In the eleventh century, the Nāgara forms appear again adding miniature temples and amalgamating simple Latina forms with the curved sikhara and interpenetrating clusters, and the newly developed Śekhari and Bhūmija modes with vertical chains of kūța-stambha (śikharas on pillars) (Hardy, 1995, 301). Consequently, the 'Vesara' shape is defined and extended as follows, "Latina in typical North Indian language, figuring curvilinear its form, provides the framework, while the Kuttina in typical South Indian language lends its decoration to the Bhūmija in the middle Indian mode." (Fig. 7) On the basis of such results, they steadily develop as representative styles accordant with the regional traditions of construction methods and stylish mixtures through political changes (Meister, 1993, 94-115; Hardy, 2002, 81-137). ${ }^{11}$
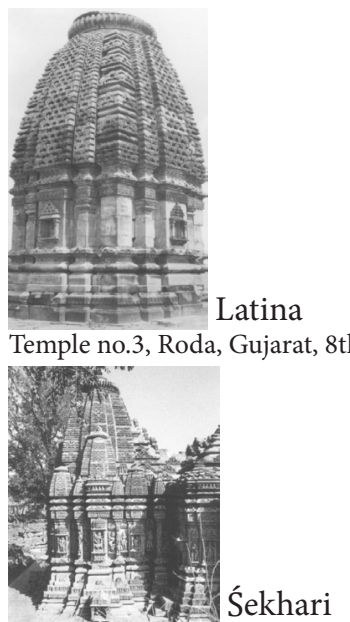

Ambika, Jagat, Rajasthan, ca. 96I

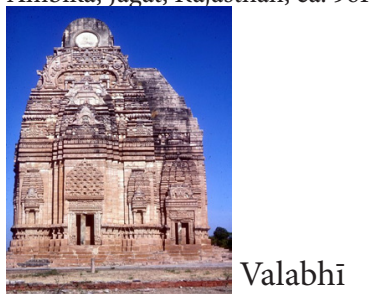

Teli-ka-mandir, Gwalior, MP 8th

Figure 8. Major types originated from Nāgara and Drāvidụa (source: author)
Temple no.3, Roda, Gujarat, 8th c

To begin with, Latina type with a vertical-banded latās (creeper) employing the arched-window shape at the end of a barrel roof and Valabhi type (the eighth century) with a barrel vaulted superstructure alike are originated from the worldly and urban wooden architectural forms, a rectangular barrel-roofed shrine which recalls a caitya hall. Phāmsanā with a tiered pyramidal roof is made up of multiple staggered awnings and pinnacles. Sekhari type with miniature copies, multiple offsets, is equilaterally extended toward the cardinal directions in the temples plan with the multiplication of miniatures, and Bhumija type is a symbol of a multiplying, multilayered, and multi-dimensional cosmos (Hardy, 1995, 7-10). Bhūmija is literally translated as "earth-born" referred to the origin of this mode in Malwa. In the same vein as said above, Latina, Bhūmija and Śekhari are three modes using the Nāgara pattern, while the orthogonal and stellate vimānas shown in them are two modes of the Drāviḍa. Phāmsanā and Valabhī are neither Nāgara nor Drāviḍa, but are afterward completed fusing with the both styles. Namely, as Krishna Deva defines the Vesara form, Latina provides the framework, while the Kütina lends to the Bhūmija its decoration (Deva, 1975, 90-113). ${ }^{12}$ Through these varied forms and transformations coined from Nāgara and Drāviḍa form, the Vesara's concomitant features show that a temple gives an influence upon brick structures like a multi-storied palace and incases a series of miniatures in the intermediated spine, forming multi-layered stories. All these styles, respectively blended but repeated, sustain significant ideas such as curved sikhara, multiplying miniatures, and intermediate spines. They hence follow the characteristic evolutions of architectural elements from a simple 
unit to progressively complex and increasingly dynamic. (Fig. 8)

There are key reasons for such changes that result from two original forms, Nāgara and Drāviḍa, extending the scale and extent of temples, are categorized into four views. First, political circumstances can be an answer. In South India, there were territorial exchanges on Badami between the Chalukyas and the Pallavas, and the quick changes of dynasties in the seventh century. Second, formalized worship and perception towards a god like an image of Śiva underwent radical changes together with changing dynasties, kings, and patrons in the Drāvida region after the Pallavas initiated their enterprise with stone temples. Third, the progressions of many new forms throughout temple complexes developed between the Pallavas and the Cholas gave an outstanding chance in evolving compound symbolic vocabularies, fundamentally altering rites of patronage and personal devotion through unifications with the already existing temples. Fourth, the Vāstupuruṣamaṇdala grids offered radical changes for temple constructions ever since the early seventh century. Their ground plans correspond to the 64 Vāstupurușamaṇdala girds suggested by Varahamihirảs Bṛihat Samhitâ (Meister, 2003). ${ }^{13}$ Most of them observe a simple principle "the inner sancta twice in width the thickness of their walls," as a result producing a fixed layout of the inner sacred space. For the sake of the practical designs, also, one of the most important considerations in temple layouts is the conjunction between the Vāstupuruṣamaṇdala grids and its walls. Most shrines in temples are gradually transformed into the Vesara superstructures with a mixture of the six styles aforesaid, and they are square in plan with a single shallow bhadra (middle projection) on three-faced external walls on the basis of a cross plan. When measured at the base of the wall's high kumbha (pitcher) molding, even the width of bhadras is equal to that of the inner sancta, based upon the Brihat Samhitâ. Simply put, the karna (corner) faces each equal half the width of the bhadra, and its proportion is 2:4:2 (=karṇa:bhadra:karṇa).

\section{THE PROCESS OF TEMPLE'S CONSTRUCTION AND VĀSTUPURUSAMANDALA}

\subsection{Combining Square with Circle to Represent the Sanctified Space}

A number of architectural practices in India during the second half of the first century CE did not survive. Although much may be learned about the education and role of architects and their relationships with priests, patrons, and craftsmen, we nearly can not know about the architects' control and the primary information used to construct Indian temples. So, with several texts which treat fundamental concepts (typically the Vāstupuruṣamaṇdala) about the construction, this thesis will deal with the process of its creation. Its construction progresses with the following phases. First of all, most prototypical stone temples are characterized by a square plan with cardinal projections (bhadra) and a curvilinear superstructure with vertical band (latās) over the wall's projections (Meister, 1979, 204-219). ${ }^{14}$ The square plan is coined from the navel (nābhi) in the Vedic rites, as a womb in the center of the UttaraVedi (upper or north altar). On the altar, the fire is laid on the Ukhā, a fire-pan made of clay. The fire (Agni) is carried in the pan from the Āhavanìyā (four-cornered fire place) hearth (Kramrisch, 1946, 26-7). Then, in line with the stipulation of Baudhāyana Sulbasūtra, the first work is to make a square (caturaśrikarana) delineating the outer periphery of the temple, its division in half, fixing a pole in the middle of the east-west line at the cardinal points. The points on its circumference which are touched by the tip of a shadow cast by the sun in the morning and the afternoon are marked. The line that joins these points lies in the east-west direction. This axis is moved to pass along the center of a circle, and a line is drawn at right angles to indicate the north-south direction (1,2 in Fig. 9).

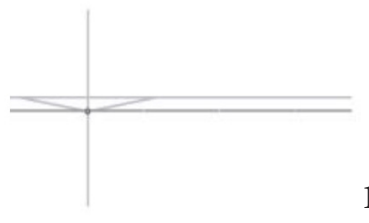

1
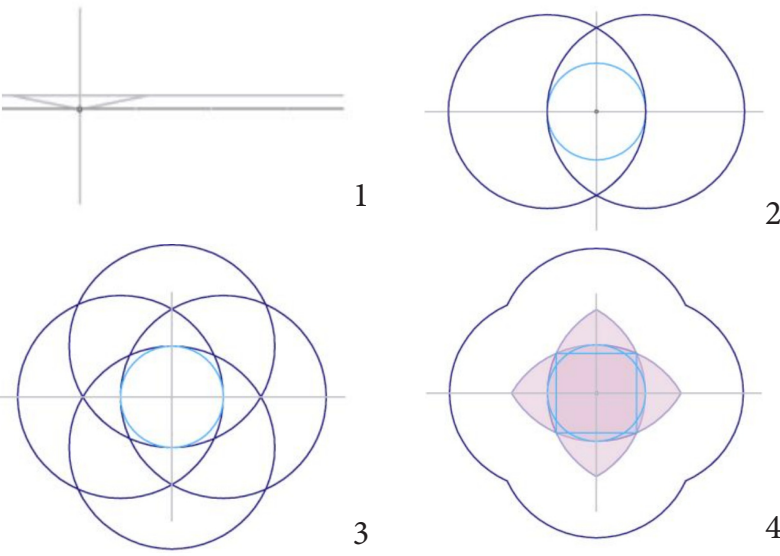

2
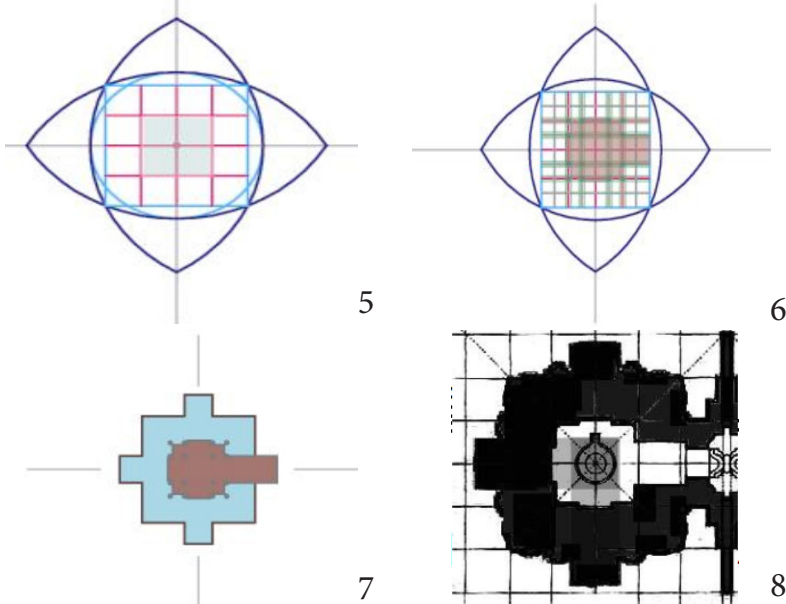

5

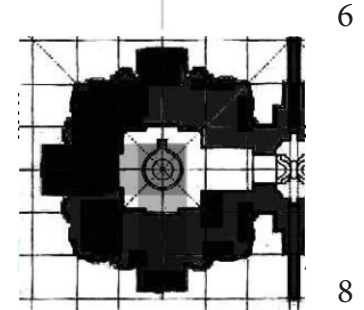

6

Figure 9. A computer-based drawing by lines, points, and grid on the Vāstupuruṣamaṇala of Brahmeshvara temple at Bhubaneshwar. The order of no. 1 to no. 8 shows its construction process (author's drawing)

Next, the circle centered by the pillar is converted into a square whose sides face the directions. In the intersection points between four circles are erected the eastern, southern, western, and northern poles each. This square is to confine the temple's sacred space (3, 4, 5 in Fig. 9). According to Varahamihira's rules, continuously the thickness of the walls is half the width of the sanctum, the temple twice as high as it is wide, the image and pedestal $1 / 8$ less than the height of the doorway (Meister, 1979, 205). These symbolic and geometric combinations between the circle and the square suggest an important rule for the size of a square sanctum $(6,7,8$ in Fig. 9). Hence, the products formed by regulating lines and points become a basic diagram and plan, overlaid on the Vāstupurușamaṇdala grids, and the corresponding points between the two diagrams prove that the temple's laying out does not depend on measurements, but the logic science by means of proportions. This geometric calculation affects all Hindu temples in significance. Continuously, expanding energy shapes the circle (the image of the 
ceaseless flux and mutuality of Earth World) from the center; it is established in the shape of the square (the image of the permanence and immutability of Heaven World). Their positions are upside down immediately when constructed as a temple. Each point which meets the circle and the square is oriented to the four cardinal directions. These points are where time and space meet, where the sun appears to rise and set, East and West. This means that the Vàstupurușamaṇala incorporates the courses of the heavenly bodies (a circle) which are related to all recurring time sequence. When it is given orientation and made fit for human habitation, the earth is viewed as the Vāstu and visualized as a square, the manifestation of the supreme principle (Kramrisch, 1946, 21 29; Volwahsen, 1969, 43-5). The neck of a great pillar above the upper slab is crowned by āmalaka (an auspicious seed) connects with the both territories in circular and square form. Extending vertically through the central sacred ground (brahmasthāna) of the sanctum, this invisible pillar marks its center on the proportional grid (Meister, 1990, 396). The superstructure's height, with the exception of àmalaka, further does not exceed two times longer than the range of the Vàstupurușamaṇdala grid diagram. The superstructures curvature begins in outline, when viewed from the side, as soon as the height of the shrine exceeds the defined reach of the Vāstupuruṣamaṇḍala (Fig. 11).
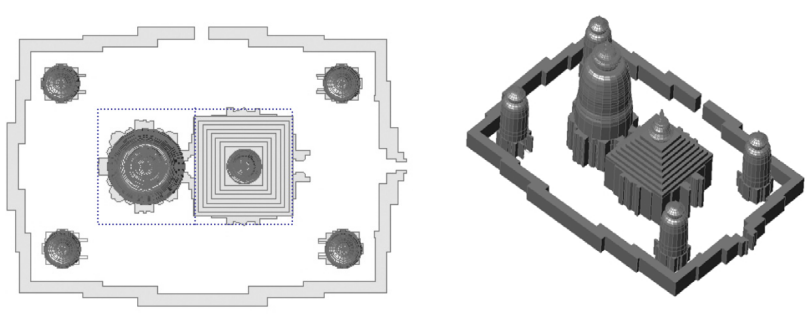

Figure 10. Brahmeshvara temple at Bhubaneshwar, a computer-based construction (author's drawings). An assembly hall has the same length and width as the garbhagrha.

As seen in Figure 9, Brahmeshvara temple at Bhubaneshwar shows us the application of the doctrine of the Vāstupuruṣamaṇdala. The sanctum around a lingam provides enough room for ritual circumambulation, containing $4 \times 4$ pādas, exactly conforming to the regulations of aforesaid grids. (7, 8 in Fig. 9$)$ The intersection between four diagonal lines from the $8 \times 8$ Vāstupurușamaṇ ḍala (mandūka mandala) toward south-east, north-west, south-west, north-east corners of the platforms and four smaller circles within the circle can draw another circular shape that defines the external walls of the temple. Based upon such repeated grids and modules of the Vāstupurușamaṇḍala, further, an assembly hall (mukhashala or mahamandapa) is separated from the garbhagrha (sanctum) with the same length and width. (Fig. 10) Through this design process, notable is that the design ideas are tailored to meet the Vāstupurușamandala grids. The procedure are divided into three stages; first, the temples persistently use a square-based plan for the representation of a Vedic altar (Kramrisch, 1946, 15) ${ }^{15}$; second, a grid work serves as a useful device to weave space and time and then situate a plan overlaid on the Vāstupuruṣamaṇdala; and, third, there are symbolic ornamentations to get an attractive sight for believers.

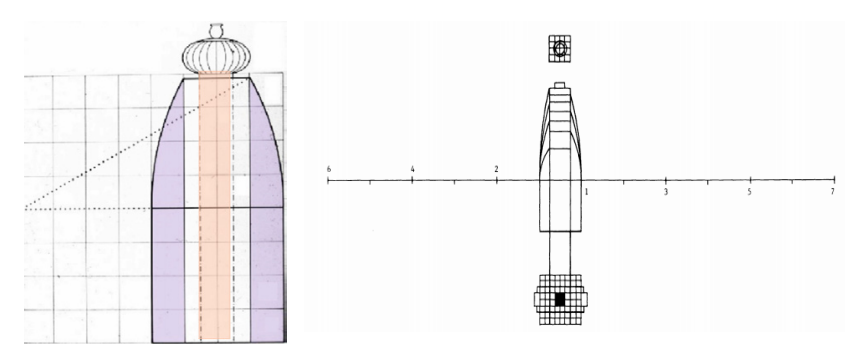

Figure 11. The relationship between Vāstupuruṣamaṇạala and temple's elevation and invisible pillar to determine curvature (source: Meister)

Like this, the Vāstupurușamandalà's crucial purpose is not for a real plan of a temple, but for its ritual ideas. The shrine and superstructure arise governing their width and height in conformity with regulating lines and points (marmas) on a diagram, rather than grids on it. Nevertheless, the Vāstupuruṣa's body on the Vāstupurușamaṇạala cannot be invariably denied on the perfect grid work because the grids in fact serve as a practical apparatus for the construction to prove the use of the Vāstupuruṣamandalala.

\subsection{Locating Divinities in the Grids}

The square-based plan, Vāstupuruṣamaṇalala, could be expressed in thirty two ways (Varāhamihira, 1947, 433-439; Kramrisch, 1946, 33, 47, 58), in accordance with the Vāstushāstras (general manuals on architecture). The Sulbasūtra manuscript as early as the fourth century BCE elaborately explains the methods and prescriptions as to the construction of Vedic altars (Meister, 1983, 266), and the Vāstupurușa overlaid by geometric rules. Varāhamihirảs Bṛihat Saṃhitâ contains the earliest description of the Vāstupuruṣamaṇdala (Varāhamihira, 1947, 433-437). The Vàstupurușa as a presiding deity of the site has six bones, a single heart, four vulnerable points, and four vessels (Varāhamihira, 1947, 440; Acharya, 1927, 38), and he lies upon the ground, with his head in the northeast corner, lying face down with his body contorted into the shape of a square (Meister, 2002, 92103; Mayamata, 1985, 21; Mayamatam (7. 49)) following the padavinyās system. ${ }^{16}$ The text indicates a grid of $9 \times 9=81$ squares for domestic buildings (house), while a grid of $8 \times 8=64$ squares for temples or shrines (Kramrisch, 1946, 46). (Fig. 14) An overall square generally sub-divided into 64 pādas (mandūka maṇḍala) ${ }^{17}$ or 81 pādas (paramaśáyika maṇḍala) on the Vāstupuruṣamaṇḍala comes from the Mayamatam. The Mayamatam provides a square (pāda) grid module and a disposition or distribution (vinyāsa) of deities as an overall framework (Meister, 1981, 77-90; Mayamata, 1985, 21; Mayamatam (7.57-58); Kramrisch, 1946, 46; Volwahsen, $1969,45){ }^{18}$ Herein, the 'pāda points out "the individual square or cell shaped from the subdivision." So, a compound of pāda and vinyāsa is referred to as padavinyāsa, which is a title of Chapter 7 of the Mānasāra. As result, it proves that the grid theory is presumably embedded onto the traditional southern thought of the grid.

Like this, this sub-divided grid diagram exists in the following three manuscripts, e.g. Brịhat Samhitâ in the northern tradition, and Mayamatam and Mānasāra in the southern tradition each. More exactly, in the Mānasāra, Chapter 36 mentions the type 
of grids appropriate for each caste and the layout of a house is decided accordingly. Together, Chapter 9 introduces some types of grids such as sthaṇdila (49 pādas), paramaśāyika (81 pādas), and mandūka (64 pādas). Similarly, the Mayamatam refers to the same building tradition. However, the Mayamatam discusses the matters more specifically, writing "the diagram for the main temple is drawn up with four squares; that for the first enclosure is the mahapitha consisting of sixteen squares (pādas), that for the second is mandūka (64 pādas), that for the third paramaśāyika (81 pādas), that for the median enclosure, the bhadramahāsana (136 pādas), and that for the forth the indrakānta (1024 pādas)." (Dagens, 1976, 387(23.2-3)) (Fig. 12, 13)

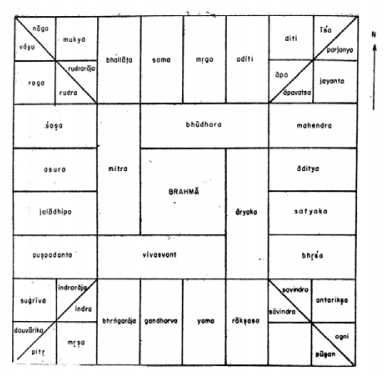

Figure 12. mandūka maṇḍala (64 pādas) (Dagens, 1976, VII 43)

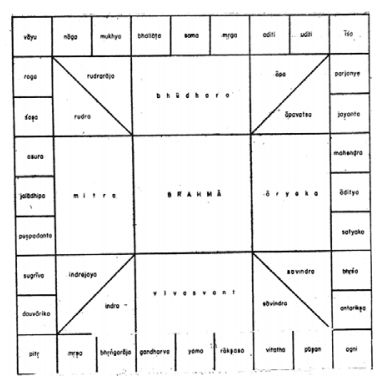

Figure 13. paramaśāyika maṇḍala (81 pādas) (Dagens, 1976, VII 58)
On the contrary, in the Bṛihat Saṃhitâ of Northern tradition, forty-five deities, following a systematic order, are arranged along three sets of concentric rings within the padavinyās grids on the Vāstupurușamaṇdala. The below-illustrated figure indicates the allocation of deities to the individual squares, and shows a four-level hierarchy, presented here by four tones. Speaking concretely, at the center is situated the Brahmā, the supreme principle. Twelve devatas form its inner ring surrounding the center, and 32 or 36 devatas (padadevatas)coinciding with lunar mansions (the Nakṣastras, a key component of Vedic astrology)-are placed along the perimeter of the Vàstumaṇdala, forming its outer ring (Varāhamihira, 1947, 433-439; Kramrisch, 1946, 85-86; Volwahsen, 1969, 4446). (Fig. 15) The Brahmā represents the central region, and the twelve deities surrounding the Brahmà are identified as the twelve Ädityas, the seven celestial deities in the Rigveda. The four sides, beginning from the east and moving toward the south, west, and north, are assigned to Aryaman, Vivasvan, Mitra, and Mahidhara respectively. The remaining eight Ādityas are arranged in pairs at each four corner: Savita and Savitra at the southeast corner, Indra and Indrajaya in the southwest, Apa and Apavatsa in the northeast, and Rudra and Rudrajaya in the northwest. These sanctified deities within the Vāstu grids are placed moving in the same direction as the sun progresses, centering the house of Brahmā (Varāhamihira, 1947, 438-439). Eight of the thirty-two padadevatas are considered to be the lokapalas (literally world protects, guardians of the cardinal points), they are composed of those in the corners and those in the middle of each side of the square, beginning from the east (pradakshina): Indra, Agni, Yama, Nirrti, Varuna, Marut, Kubera, and Isana (Varāhamihira, 1947, 433-439; Kramrisch, 1946, 30, 88-97; Keilhauser, et al. 1990). ${ }^{19}$ (Fig. 15)

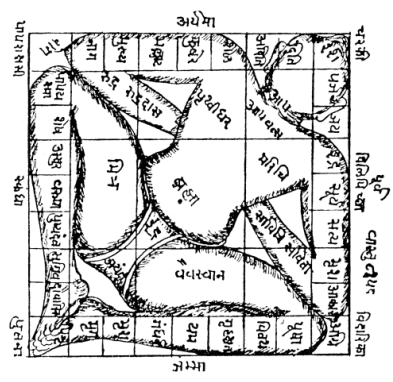

Figure 14.Västupuruṣamaṇḍala with Vāstupuruṣa (source: Kramrisch)

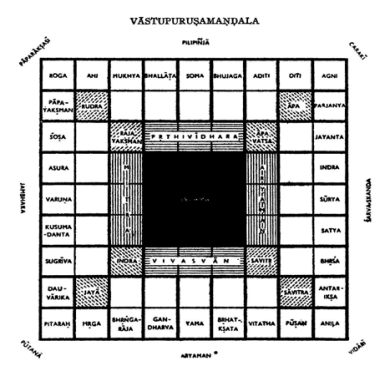

Figure 15. Vāstupuruṣamaṇḍala and 81-pādas (source: Kramrisch)
This image of dikapalas (the guardians of the four directions) and the lokapalas are displayed at the walls of temples, through diagonal and central deities in each niche performed on the four directions. Particularly in case of the dikapalas, it comes out as an invariably set on temples walls late in the seventh century or early in the eighth century CE (Meister, 1981). As the Vãstupurușamaṇdala begins to be closely related to an Indian horoscope, further, astrologers apply the zodiac into the mandala, and put its twelve signs within the twelve squares for the outer gods (Volwahsen, 1969, 45). These thirty-three devatas are additionally commonly mentioned in the Vedic literature. But, their positions are not accurately accorded with those of the padadevata. ${ }^{20}$

From this discussion, we can recognize that on the Vàstupurușamaṇdala the allocation of deities in each cell of a grid plan prescribes various functions by means of each feature and hierarchy of the divinities. When they are superimposed on it, the Vāstupurușamaṇạala sanctifies the grid work that employs the avatars which guard it from evil influences.

\section{DEFINING THE VĀSTUPURUSAMANDALA IN COMPARISON WITH VASTUSUTRA UPANISAD}

The Vastusutra Upanisad has some resemblances with Vāstupurușamaṇdala in that a few principles are especially mentioned about the grid work. The sequence of grid lines is drawn on the stone panel as the purușa with sixteen parts, and classified into five types: the field of Brahmā, of the gods (daiva), of living beings (jaiva), of secondary divinities (upadaiva), and of worshippers (stuvaka). The forms within the grid of sixteen compartments are best for making images, and the hole is the manifestation of Brahmā (Boner, 1996, 79-81). The different deities are placed within sixteen parts each. To be exact, in the two uppermost compartments, Yaksa, Gandharvas and Apsaras should be carved. The corresponding two lowest compartments are the places for adorers. In both corners human worshippers should be drawn. The two lowest central compartments are the place of living beings for the vehicles of divinities. The four central compartments as a core are the field (kșetra) of Brahmā where the body of the image for worship is established. The four compartments left and right of the brahmākṣetra are the places for Brahmās consorts. This composition has a striking likeness with that of Vāstupurușamaṇḍala. (Fig. 17)

The Vastusutra Upanisad likewise refers to the process of making of a $4 \times 4$ orthogonal grid called khila-pañjara as an altar. The first 
is setting and polishing the stone, and on the stone panel sthāpaka (an architect-priest or a craftsman) skilled in the manual processes of building and the craft of construction draws a double circle form by applying them into the model of prakrti (everything else) and purușa (the Supernal Man) which, according to sthāpaka's instructions, are carried out by sthapati, an architect, who is skilled in making temples and knowledgeable in the treatises. Like this, the way of drawing a square, using double circles and cords, is closely akin to the Sulbasūtra. Continuously, by the line the sthāpaka partitions the circle, as the creators by their action divide the world. The territory, after all, is encased by four lines like a water tank, and due to the repetition of the cosmic laws the Vāstu place (the square or rhombus) is placed again inside the circle (Boner, 1996, 45-50). Like the preceding, a round altar symbolizes the terrestrial world, whereas a square altar means the celestial. (Fig. 16)

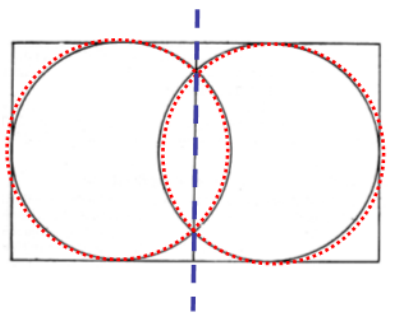

Figure 16. A way to draw a square in the Vastusutra Upanisad (author's drawing)

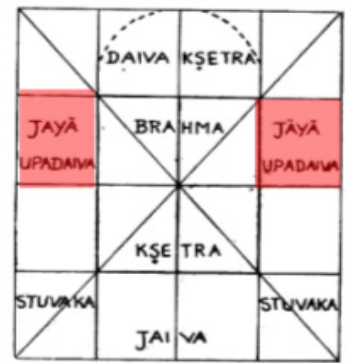

Figure 17. A line drawing in the Vastusutra Upanisad (source: Boner)
This process to make a geometric form also has some affinities with the Vāstupurușamaṇdala. It could be explained as regards the associations with the Vedic sacrificial rite by the Aryans. Though there are much difference between the khila-pañjara and the Vàstupurușamandala in that there are dissimilar mechanisms in constructing ritual programs in a sanctum the Vāstupuruṣamaṇdala does not consider worshippers, they surely indicate perfect and absolute forms through the deities' sanctification, and, if sixteen compartments $(4 \times 4$ grid $)$ define a sanctum except for the projections of walls, they might have a sense of scale and proportion in common although they specify different measurements.

Moreover, the Vastusutra Upanisad, unlike other texts like Brịhat Saṃitâ, Mayamatam, and Mānasāra, points out the detailed roles of sthāpaka which term itself encompasses a range of practical building tasks. According to the Vishnudharmottarapurana compiled in the sixth century, the sthāpakas consist of three distinct parts: sūtradhāra (string holder) who measures; taksaka (stonemason) who cuts; and vardhaki (carpenter) who is responsible for scaffolding and machinery for lifting stone blocks. The sthāpakas thus measure out and place the measured parts going from below upwards according to the law of proportion. (Boner, 1996, 64) The correct delineation of the grid is very important because its efficacy becomes dumb when it transgresses its measurement. Rather, these rules on architecture are originated among communities of priests for the stated purpose of ensuring the ritual efficacy of the completed temples; e.g. the ability of temples to allow the increase of merit (punya) for architects who design them and supervise their construction, for the craftsmen who construct them, for the patrons who pay for them and worship the images of deities within, and for the priests who maintain the images and ritual processes. (Shah, 1999)

This indicates that the sthāpaka is very significant in carrying out the practical designs and constructions of temples, rather than sthapati, and they put stress on the stone's measurements and its numbers to get the accrual of merit and efficacy through the correct construction and rituals. As a result, sthapati is rather directed by sthāpaka. These facts reflect that they are entirely responsible for both inventing the construction methods of temples and taking load bearing systems through the measurements and the numbers of stone into account in keeping with the law of proportion, already suggested by most of buildings manuals. This means that the sthāpaka takes structural supports and processes of construction into consideration, while sthapati just performs the construction of temples according to their instructions. Hence, sthāpaka is placed as the most essential architect in carrying out the foundation of temples.

\section{AMALGAMATING ORNAMENTATIONS WITH THE VĀSTUPURUSAMANDALA}

Centering on the altar and the performance of sacrifice, rather than the images of the divines, as a turning point Hindu structures accepted the divines decorated by the image in the first centuries CE (Meister, 2002, 92-103). The deities who remained the unseen in ancient India began to present an anthropomorphic form as a Hindu icon. A notable idea is that the buttresses (bhadra or ratha $^{21}$ ) facing the four cardinal directions are analogous to the form of a four-faced Śiva-linga. In the middle Vedic age, the linga cult became comparatively more popular. The symbol of Siva, the linga, is a cylinder rounded at the top. This is visualized by a form which has four faces to the cardinal directions, emerging from its central pillar (Kramrisch, 1958, 7-13). Human images are actually combined with architectural figures in north India from the first century BCE or the first century CE. But, the aesthetic fashion for carving sculpture is more developed between the fourth and sixth centuries, laying stress on the independent images. In the more intricate monuments constructed from the seventh century onward, the sacred images by degrees occur with an overall compositional scheme, easy to cognize in a distance, at the same time more and more abstracting human forms. That is, these large compositions are more gradually emphasized on compositive and unified monuments, particularly with anatomical articulation, exaggeration of movement, hardening of carving, bold elaboration of details, and reduction and multiplication of single images between the sixth and fourteenth centuries. They are more evolved and developed by the artistic trials of architect-priests between seventh and thirteenth centuries (Mason, 1993, 116-137). ${ }^{22}$

Also, through repeated ornaments expanding outward and producing a vivid sense of symbol, the temples move from smaller to larger versions of the same image, from non-identical forms to identical, or else similar cluster to dissimilar. On the external wall's elevations, the frieze sections of the walls between cornices and binding moldings have lucid logics in the process of establishing their locations, and lead to fixing an iconographic program on the monuments. The central buttresses or offsets (bhadra) from monuments with figured walls (from the sixth century onward) 
hold the reflections of the sanctum's divinity. Likewise, the images on the bhadra projections have a narrative order, logically locating them on the bhadras and emerging only on bhadras in the early eighth century (Mason, 1993). The images begin to appear first on the corners (karnas) of shrines and then on the intermediary offsets, with logical proportions. Through the very complicated process of continuing downwards to the cardinal directions, simultaneously, the sacred hierarchy towards the heavens takes place in a dynamic process of manifestation (Hardy, 1997, 107-8; 2002). In this context, grids and squares play outstanding roles in mediating its rigid structures and anthropomorphic conception with flexible proportions. On the contrary, it hides structures from the ominous ideas and hierarchy of gods, from the ominous eyes of the unskilled (Kramrisch, 1946, 60-61). Besides, only with the Vāstupurușamandala we cannot feel the characteristics and the quality of its space. What we only can see with the naked eye is the superstructure of a temple constructed by walls from below upward. But, through the patterns of offsets (bhadra) or the enshrinement of gods on each side of the temple, the temple symbolically reveals a desire as a setting to dismantle the territories between man and the God. Such symbolic notions have a strong association with the very form and materials of the structure, and even more we can feel a hierarchy in the course of the external expansion of mandala which continues downwards from heaven. Accordingly, as a house of the Gods, the massive sense could be more underlined by walls' ornament to consecrate the temple. But, these walls are in due degree and rules limited along an overall quarter and grid lines based upon the Vāstupurușamaṇdala.

As a consequence, temple architects were admittedly significant inheritors for its oral transmission as to architectural rules (vāstuśāstras). But, as aforementioned, I do not think that they would control all works of a temple as chief masters because the Hindu temple reflects a number of ideas from astrology and astronomy through ritual managements. Of course, architects should know all related sources although generally it is impossible to do it. Thus, we cannot know that they were all authors on the architectural rules. Rather, these particular rules on the building construction were originated from architect-priest (sthāpaka)'s craftsmanship proficient as a stonemason and a carpenter in the labor-intensive processes of the temples' construction for proper measurements and cuts of stone and wood, which were directly associated with structural stability of the finished temples.

Therefore, the ornaments of temples including both anthropomorphic forms and variegated decorations act in place of the grid, and simultaneously serve as the basis of the building for structural stability and rigidity, and, paradoxically, they lead to hiding the geometrical diagram outlined on the Vāstupuruṣamaṇụala.

\section{CONCLUSION: REVISITING THE MEANING OF VĀSTUPURUSAMANDALA}

Grid lines in the Vāstupuruṣamandala are a design tool for ritual processions to deploy gods in three dimensions, and get a good place and a hierarchical arrangement like a zoning planning. Once the site of a temple is selected and ritually purified through an abhișheka ceremony, the next stage in its erection is the layout of the ground plan, which is controlled by means of the conceptual diagram of the
Vāstupurușamaṇdala. At one time, temple architects mediate walllines of the building with a number of points (marmas, intersection) on the body of the Vàstupurușa, according to the Brịhat Saṃhitâ and Mayamatam, for the well-being of the building. In deciding the wall-lines of buildings, a remarkable point is that a chief norm is to avoid the marmas located on the body of the Vāstupurușa for its efficacy (Mayamata, 1985, 21 or See Mayamatam (7.55-56)). ${ }^{23}$ In the temple's plan, thus, the location of these marmas affects the positions of the building's wall-lines. As shown in the north Indian mandūka-mandiala with the $8 \times 8$ pāda, the points of intersection (marmas) must not be interrupted by the line of the ground plan. No constructions should be disallowed upon crossing points, other lines of the padavinyās diagrams, or else the worshipers and the territory of the surrounding circumstances could be harmed. It thus cannot be denied that the Vāstupurușamaṇạala grid is looked upon as an idea and a tool that have been consistently redefined and exploited through history. Conversely, as aforementioned, the application of such regular modulated squares reflects that sthāpakas encompass a range of practical building tasks intimately connected to measurements and cuts of stone and wood, and further they decide the related matters considering load bearing structures.

The application of the grids, in this sense, would be a significant means for unconscious symbol between the God and laymen, in addition to an essential support of dynamic superstructure. However, when structural troubles would happen in the early Hindu temple, the temple would be more serious if it would have a superstructure with the sikhara made of crudely-made brick because it needs to solve structural loads. But, these structural conflicts would disappear naturally when the temples are set out according to the correct criteria, and when architects take measurements and numbers of stone or brick into consideration, both coming along with the Vāstupuruṣamaṇ ḍala grids and situating ornaments with embedded sculptures along the walls extended outward because their enshrinement is the first purpose of the temple itself. Also, when the height and width of temples become bigger together with the great śikhara by aesthetic and political demands, the strong materials and efficient solutions of structural problem would be naturally demanded. So, architects use strong materials like stone or brick, which becomes steadily developed for the construction works on modulated grids, the Vāstupurușamaṇạala. As an ultimate solution, the offsets (bhadra) of the walls get more supported by pilasters, reflecting emblematic and aesthetic points. After all, the multiple projections of all walls along with the main buttresses (bhadra or ratha) are extended outward and become more complex by embedded sculptures on them. What is more obvious is that the form of the buttress takes the architectural proportions and modules into account according to preferred styles in each region: e.g. Nāgara, Drāviḍa, Vesara, Latina, Bhūmija, Valabhī, Phāmsanā, and Śekhari.

Also, for temples built of stone, the first bricks are of stone; for shrines built of wood, they are of wood, or else earthen bricks are employed for all kinds of temples (vimāna). By its symbolic significance brick has precedence over stone and wood. Stone is used as its substitute. Their altars are also brick piles and embodied metaphysical knowledge (Kramrisch 1946, 108). Temples built on bricks is suitable in modulating their number and size for constructing them before the introduction for projecting vertical buttresses, and arranging the bricks in accord with the crossing 
points of the grid, even satisfying measurements and structural loads. Accordingly, the brick construction is useful corresponding to the crossing points of the grid, and so had superiority over stone and wood. But, when the whole scale of temples is on the increase in the ritual authority and, for that reason, when the Vāstupuruṣamaṇạala is introduced for the constructions, it could be not rational and economical to use the brick too much in order to keep the Vāstupuruṣamanduala in proportion, and even it is unstable for structural load bearing capacity. Thus, by employing stone as a main material, the matters of the allowable load and adjustable proportion get solved. In deciding the size and measurement of compartments sub-divided within the square plan, architects would consider structural loads drawing on the width and height of a temple plan. In other words, the higher the temple would be, the larger its squares would be and the thicker the buttress and even the inner walls would be. Further, in its construction there must be regular rules like a modular system which are decided by allowable load designs founded upon the height and thickness of walls though it is not clear from the textual prescriptions, while it might be impossible to find a standardized rule because this could lead to the plans of quite different dimensions.

Likewise, this article positively adds Meister's observation as the ritual grid of the Vedic altar, the Uttar Vedi. As Meister exclusively points out, there would be a kind of benchmark to be considered before the demarcations of square and the construction of walls. The ancient architects measure off lines, points, and a basic cell for an altar, based upon the height of socles (vedibandha) in accordance with the floor level of an inner sanctum (Meister, 2003, 258-259), ${ }^{24}$ regarded as a reference point to lay out the Vāstupurușamaṇạala. A notable view to support his works is that from the seventh century onward Hindu temples have persistently kept the original dimension of a sanctum with a 'square-based plan' to determine the rhythm of the architectural members or the proportion between the thickness of the walls and the size of the inner shrine. It is strongly in conjunction with the early creation of temples through the logical harmony between the circle and square. It is shown that a fixed square form means a symbolic space in coincidence with a purpose for the ritual program. However, Meister, on the Vāstupurușamand dialàs application to the construction of temples, just contends that it flexibly controls design's proportions in their ground plans and sectional elevations, and has continuous relations with the ritual grid of the Vedic altar as a ways to consecrate temples and protect them (Meister, 1985, 248-258; 1981, 248-249). Rather, to my knowledge, as mentioned earlier through the field works of archive materials, the Vāstupurușamandala reflects the two concerns; the one is practically for a constructional aid as a design process; and the other is spiritually for an emblematic metaphor.

Last but not least, in Indian culture, architecture is viewed as a representation of an institution (Thapar, 2002, xxix), and both institutional and symbolic needs would determine its form. In many ways, also, narrative sources connected more specifically with architecture provide a bridge to present ultimate meanings for the constructions, whether they are stories concerning the Buddha's life or the Hindu deities' mythology (Kim, 2011a, 183-192). The Vedas primarily referred to as a kind of manuals for rituals and commentaries provide a model of square-planned altars made of timber and reed, for which Vedic shelters offer a vocabulary (Renou, 1998, 130-141). The square-based plan with two dimensions is an archetype and a pattern of order, while the square-based form with three dimensions encased by Hindu icons to the four cardinal directions is a chief element in accommodating ritual intentions and load bearing systems overlaid upon the Vāstupurușamaṇḍala. Further, its geometric plan leads to constructing a temple with regular proportions, tallying with symbolic meanings and practical ends. For such reasons, these dominant ideas can be considered as a driving force that the size of shrines for rituals have been persistently maintained without any spatial changes, although there have been even greater extensions of the support material and the symbolic surface.

In these overall perspectives, this thesis attempts to redefine the meaning of the Vāstupurușamaṇala by combining practical construction methods with symbolical places to make a sanctified temple. In the construction of Hindu temples, the Vāstupurușamaṇa dala's rule contains emblematic theory and functional practices supervised by ancient Indian architects (sthāpaka), and its architectural representation consequently makes it possible for them to have persistently kept the original dimension of a sanctum with a square base plan from the seventh century onward.

\section{REFERENCES}

Acharya, K. P. (1927) Indian Architecture according to Mānsāra Silapaśāstrea, the Oxford University Press.

Bafna, S. (2000) "On the Idea of the Mandala as a Governing Device in Indian Architectural Tradition," The Journal of the Society of Architectural Historians, 59(1), 26-49.

Boner, A., and Śarmā, S. R. (1966) Silpa Prakasa Medieval Orissan Sanskrit Text on Temple Architecture. Brill.

Boner, A., et al. (1982) Vastusutra Upanisad: The Essence of Form in Sacred Art. Delhi: Motilal Banarsidass.

Dagens, B. (1976) Mayamata traité sanskrit d'architecture. Deuxième partie.

Dagens, B. (1985) Mayamata, an Indian Treatise on Housing Architecture and Iconography, Sitram Bhartia Institute of Scientific Research, New Delhi, India.

Deva, K. (1975) "Bhūmija Temples," Studies in Indian Temple Architecture, ed. Pramod Chandra, New Delhi: American Institute of Indian Studies, 90-113.

Dhaky, M. (1977) the Indian Temple Form in Karnata Inscriptions and Architecture, New Delhi: Abhinav Pub.

Hardy, A. (1995) Indian Temple Architecture: Form and Transformation : the Karnāta Drāvida Tradition, 7th to 13th Centuries. Abhinav Publications.

Hardy, A. (1997) "Form, Transformation and Meaning in Indian Temple Architecture," Paradigms of Indian Architecture, Giles Tillotson ed. London: Curzon Press.

Hardy, A. (2001) "Tradition and Transformation: Continuity and ingenuity in the temples of Karnataka," Journal of the Society of Architectural Historians 60, 180-199.

Hardy, A. (2002) "Śekhari Temples," Artibus Asiae vol. LXII no. 1, 81-137.

Kauțalya (2004) Kauțilīya Arthaśāstra, Vijay Kumar Gupta, ed. Bharatiya Kala Prakashan.

Keilhauser, A. and Keilhauser, P. (1990) Die Bidsprache des Hinduismus: Die indishe Götterwelt und Ihre symbolic, DuMont Buchverlag, Köln. 
Keith, B. (1928) History of Sanskrit Literature, Oxford.

Kim, Y. J. (2011a) Architectural Representation of the Pure Land, Doctoral Dissertation, Univ. of Pennsylvania.

Kim, Y. J. et al. (2011b) "Evolution, Transformation, and Representation in Buddhist Architecture," Architectural Research, 13(4), 31-42.

Kramrisch, S. (1946) The Hindu Temple, Univ. of Calcutta.

Kramrisch, S. (Feb. 1958) "Wall and Image in Indian Art," Proceedings of the American Philosophical Society, 102(1), 7-13.

Mason, D. (1993) "A Sense of Time and Place: Style and Architectural Disposition of Images on the North Indian Temple," Gods, guardians, and lovers: temple sculptures from North India, A.D.700-1200, New York: Asia Society Galleries \& Mapin Pub., 116-137.

Meister, M. (April-June 1979) "Mandala and Practice in Nāgara Architecture in North India," Journal of the American Oriental Society, 99(2), 204-219.

Meister, M. (1978) "Construction and Conception: Mandapîka Shrines of Central India," East and West 26, 409-418.

Meister, M. (1981) "Mundésvari: Ambiguity and certainty in the analysis of a temple plan," Kalādarśana: American Studies in Indian Art, New Delhi, 77-90.

Meister, M. (1982) "Analysis of Temple Plans: Indor," Artibus Asiae 43, 302-320.

Meister, M. (February 1983) "Geometry and Measure in Indian Temple Plans: Rectangular Temples," Artibus Asiae 44, 266-296.

Meister, M. (1985) "Measurement and Proportion in Hindu Temple Architecture," Interdisciplinary Science Reviews 10, 248-258.

Meister, M. (1986) "On the Development of a Morphology for a Symbolic Architecture: India," Res, Anthropology and Aesthetics 12, 33-50.

Meister, M. (1989) "Prâsâda as Palace: Kûtina Origins of the Nâgara Temple," Artibus Asiae 49, 254-280.

Meister, M. (1991) “The Hindu Temple: Axis of Access," Concepts of Space, Ancient and Modern, Kapila Vatsyayan, ed., New Delhi: Indira Gandhi National Centre for the Arts \& Abhinav Publications, 269-80.

Meister, M. (1993) "Fragments from a Divine Cosmology," Gods, guardians, and lovers: temple sculptures from North India, A.D.700-1200, New York: Asia Society Galleries \& Mapin Pub., 94-115.

Meister, M. (2002) "Giving Up and Taking On: The Body in Ritual," Res 41, 92-103.

Meister, M. (2003) "Vāstupurușamaṇdala: Planning in the Image of Man," Gudrun Bühnemann, ed. Mandalas and Yantras in the Hindu Traditions, Leiden: Brill, 251-290.

George, P. (1998) "Counting curvature: the numerical roots of North Indian temple architecture and Frank Gehry's digital curvatures,' Res 34, 130-141

Renou, L. (1972) Religions of Ancient India, Schocken: New York.

Renou, L. (1998) “The Vedic house," edited and with a preface by Michael W. Meister, Res 34, 130-141.

Shah, P. ed. (1999) Vishnudharmottara-purana, Parimal Publications.

Sharma, R. S. (2000) Ancient India, National Council of Educational Research and Training.

Snodgrass, A. (1990) Architecture, Time and Eternity: studies in the stellar and temporal symbolism of traditional buildings, vol.1.
Srinivasan, K.R. (1975) “Temples of the Later Pallavas”, Studies in Indian temple architecture, Pramod Chandra, ed. New Delhi: American Institute of Indian Studies.

Staal, F. (1984) Agni, the Vedic Ritual of the Fire Altar, 2 Vols. Delhi: Morila Banarsidass.

Tartakov, G. M. (1980) "The Beginning of Dravidian Temple Architecture in Stone," Artibus Asiae 42(1), 39-99.

Thapar, R. (2002) Early India: From the Origins to A.D. 1300, Penguin.

Varāhamihira (1947) Varahamihira’s Brihat Sampitâ, trans. by Panditabhushana V. Subrahmanya Sastri, et al. Soobbiah and Sons.

Varāhamihira (1884) The Brihat Saṃhitâ of Varaha Mihira, South Indian Press, 2 Vols.

Volwahsen, A. (1969) Living architecture: Indian, English trans. Ann E. Keep, London: Macdonald \& Co.

(Received January 13, 2014/Accepted June 10, 2014)

\section{ENDNOTES}

\begin{abstract}
A spatial composition in stone temples is to some degree analogous to the temples of Parthian and Greco-Roman megaron, together with the meaning as a house of God (devagriham).

2 In the building of altars, bricks were used to form an orthogonal frame, and then altered with a variety of shapes to suit ritual purposes. The grid of later mandalas has one source in the piled-up bricks of such sacrificial surfaces.

3 The oldest surviving Hindu temples were built by the Chalukyas at Aihole during the Gupta era, ca. 350 to 650 CE. In contrast, for South India, in the seventh century stone temples started to be founded at Mahabalipuram, Tamil
\end{abstract} Nadu.

4 The site suitable for Brahmins is square, white, without defects, planned with udumbara trees. Most religious texts recommend a square hall for a house of gods.

5 First, Meguti temple has no images whether in the inner shrine or roof shrine other than Jaina image within the temple's sanctum as a later addition. But, it is a sāndhāra vimāna, e.g. it has a path to conduct a circumambulation of the inner sanctum enclosed within its vimāna wall. It also faces the north containing a mandapa hall, showing a typical feature of temple architecture in the seventh century. Second, the Lad Khan has Surya in his chariot on the west side of the upper shrine, along with Yaksi on the north side, and a standing Visnu on the south.

6 In a similar vein, the prosperity of stone temples suggests an association with that the Brahmans accumulated innumerable wealth through land gifts kings granted and got many privileges from kings (Sharma, 2000).

7 There are two typical types about the maṇapikā with a flat-roof, twopillared entry porch, and four-faced shrines; first, the Mahua temple set up in honor of a local ruler's deceased parents is square in plan with a twopillared entry porch (prāggrīva) projecting to the east. The base slab is square in plan, backing up basal vedibandha moldings - a shallow kumbha, kalaśa, and kapotapālī; second, the temples at Gyaraspur and Kuchdon which rest on four inner pillars show an undecorated recess supporting a second chādya (low pitched) roof, with each side shading large jali(mesh) - screen windows and shallow nāsikās (projected arched openings) set against the four sides of a Nāgara tower.

8 The word 'silpa' means "decoration, ornament, work of art," whereas 'praksa' "having the head turned eastwards."

9 Putting to use a gnomon situated at 0 , an east-west line could be decided 
and given whatever length was intended for a plan. Circles drawn from eastwest points of this line situate a north-south axis at right angles cutting in half EW. A circle from 0 with EW as diameter locates due north and south points. Circles with the same radius, drawn from the four cardinal points, place the corners of a square.

10 This will be much clearer from the following texts. In the Svayambhuvagama, the building which is square upto the stūpi is Nagara. In the Karanagama, the building which is square from the base to the stūpi is Nagara. In the Ajitagama, the Nagara is square from the base to the stūpi. In the Mayamata, the temple which is square upto the stūpi is Nagara. In the Mānasāra, the building which is square is Nagara.

11 This unified Latina (formula with latās) temple spread rapidly across North Indian and into the Deccan by the seventh century.

12 Michael Meister also talks about the Vesara through the mixture of Kütina with Latina framework by regional preferences.

13 The square Gupta temples - Sanchi 17, Tigawa, Nachna, and Deogarh use thick masonry walls to surround an inner sanctum with half the width of the whole.

14 The Brihat Saṃhitâ prescribes rules regarding orientation that the temple should always be oriented toward the cardinal points.

15 The Vedic rites start and come with the construction of temples. At the beginning of the various phases in the construction and consecration of temples, the rite of seeds and their germination (ankurārpana) is most important. Plowing and sowing a sacrificial ground with all kinds of grain precede the piling of the fire altar and the building of temples (Vaikhānasāgama).

16 The male figure of the Vāstupuruṣamaṇala represented the demon, the first sacrifice, and his transubstantiation through sacrifice into the guardians of all constructions.

17 The $8 \times 8$ grid squares determined proportions and placement of parts for the square Nagara temple in the seventh century.

18 The one is formed by dividing the side of the squares into even numbers of parts, whereas the other is formed by dividing the sides into uneven numbers of parts.

19 In the mandala, Surya as a sun-god occupies the middle point due the east. Indra also does the position as the Lord of sky; Varuna, that of ocean, to the west; Kubera, that of Wealth, to the north, only Dravidian sources before the Arian era; and Yama, that of Death, to the south. Over the mandala, there are the assigned and beneficial or otherwise attributes of gods established through other regional myths, even the arrangement of a city or a building. See Fig. 15.

20 Isana is not mentioned in all treatises as the governor of the northeast. Agni holds the position in the earlier sources.

${ }^{21}$ The ratha means a chariot; the wall symbolically comes outwards from its own midst. The niche has an image of the deity like a rider in a chariot, ghanadvāra (meaning "solid mass door for the deity"), to whom the temple is consecrated. No one can enter through the door, but the deity inside the temple has become manifest on the wall through it.

22 Between the fourth and sixth centuries, the power of the Gupta Empire led to uniformity in sculpture throughout north India. After the sixth century, when the stone buildings proliferated and independent powers arose, characteristic regional styles came forth and matured.

${ }^{23}$ The wise must avoid tormenting his limbs with the limbs of the house, or else sorrows will fall upon those of the house owner.

${ }^{24}$ When measured at the root of their wall moldings (khura hoof of vedibandha), the mandala grid is exactly overlapped matching the floor of the sanctum. 